\title{
ANALISA EFISIENSI PENJEJAK SINAR MATAHARI DENGAN MENGGUNAKAN KONTROL ATMEGA16
}

\author{
${ }^{1}$ Agus Supriyadi, ${ }^{2}$ Jamaaluddin Jamaaluddin \\ ${ }^{1,2}$ Teknik Elektro Universitas Muhammadiyah Sidoarjo
}

\author{
${ }^{1}$ Agussupriyadi120@gmail.com \\ 2Jamaaluddin@umsida.ac.id
}

\begin{abstract}
Abstrak - . Solar cell dikenal selama ini masih banyak memiliki kekurangan dalam hal pemasangan dan posisi terhadap matahari, sehingga kinerja solar cell dalam pengisian baterai tidak maksimal. Oleh karena itu diperlukan alat tambahan sebagai pendukung agar solar cell dapat bekerja maksimal, dan arus listrik yang dihasilkan lebih besar. Penjejak sinar matahari dengan sistem $L D R$ sebagai sebagai sensor untuk mengarahkan ke cahaya sinar matahari akan dibandingkan dengan system pasif. Atmega16 sebagai control motor dan auto carger, $L D R$ sebagai penerima cahaya matahari, motor dc dan steper sebagai pemutar arah ketitik cahaya sinar matahari. Solar cell yang digunakan dengan kapasitas 20 WP. Dan sistem auto carger menggunakan mikrokontroller lebih efisiensi biaya dan pemasangan. Setelah kedua system akan dibandingkan terlebih dahulu guna mengetahui perbedaan seberapa besar daya yang dihasilakan dengan system solar cell dengan menggunakan tracker dan yang pasif. Pengambilan data akan dilaksanakan selama satu minggu dengan sitem tracker dan satu minggu dengan sistem pasif. Dengan hasil data yang akan di dapat dianalisa perbandingan system dan diketahui seberapa besar efisiensinya. Di harapkan dengan sistem tracker solar cell dapat meningkatkan pengisisan baterai lebih cepat dibandingkan dengan posisi pasif,
\end{abstract}

Kata kunci: Solar cell, Penjejak Sinar Matahari, Mikrokontroller, Atmegal6

Abstract - . Solar cells known so far still have many shortcomings in terms of Mounting and positioning against the sun, so the performance of solar cells in Battery charging is not maximal. There fore additional tools are required As a support for the solar cell to work optimally, and the electric current Is generated larger. Sunlight tracking with LDR system as As the sensor to direct to the sunlight rays will be compared With a passive system. Atmegal6 as motor control and auto carger, LDR As a recipient of sunlight, DC motor as a direction player Sunlight. Solar cell is used with a capacity of 20 WP.And auto carger system using microcontroller is more costefficient and installation. After the two systems will be compared first in order Know the difference how much power generated by solar system Cell using a tracker and a passive one. Data retrieval will be Implemented for one week with sytem tracker and one week with Passive system. With the results of data to be in can be analyzed system comparison And known how much efficiency. Expected with a solar tracker system Cell can increase battery charging faster than with Passive position.

Keywords: Solar cell, sun tracker, microcontroller.

\section{PENDAHULUAN}

Listrik merupakan kebutuhan yang tidak dapat ditinggalkan dalam kehidupan sehari hari maupun dunia bisnis dan industri. Karena perangkat kehidupan sehari hari banyak menggunakan sistem energi listrik, sebab kemudahan kemudahan dalam pemakaian dan pengoperasian[1].

Sebagian besar pembangkit yang di gunakan dalam produksi listrik saat ini masih banyak menggunakan bahan bakar batubara, sisanya menggunakan Pembangkit Energi Panas Bumi, Pembangkit Listrik Tenaga Diesel (PLTD), Pembangkit Listrik Tenaga Surya (PLTS) dan masih banyak konversi energi yang di gunakan dalam pembangkit listrik walaupun dalam skala kecil[2].

Indonesia sebagai negara tropis yang memiliki 2 musim masih mengalami sinar matahari dengan waktu yang lama sekitar 8 jam/hari dari pada negara yang memiliki 4 musim. Sinar matahari di Indonesia dapat digunakan sebagai pembangkit tenaga listrik melalui media PHOTOVOLTIC (solar cell) sebagai pengkonversi energi terbarukan.

Pemasangan dengan system pasif dirasa masih kurang maksimal dalam pengambilan panas dari sinar matahari, dikarenakan ada sisa waktu dimana kondisi matahari masih panas dan solar cell tidak bisa mengambil energi tersebut karena posisi solar cell tidak tepat $90^{\circ}$ dengan sinar matahari.

Oleh karena itu perubahan system pengambilan energy sinar matahari agar lebih maksimal itu sangat perlukan. Pada penelitian ini akan di buat "ANALISA EFISIENSI PENJEJAK SINAR MATAHARI DENGAN MENGGUNAKAN KONTROL ATMEGA 16" Metode pengarahan papan solar cell secara kontinu dapat memaksimalkan dalam menyerap energy sinar matahari yang dikontrol secara otomatis dengan menggunakan 
mikrokontroler atmega16, dengan media sensor cahaya sebagai pendeteksi kemana arah cahaya matahari bergeser dan mikrokontroller memutar motor sebagai penggerak mekanik dudukan solar cell dan berhenti sampai posisi $90^{\circ}$ terhadap sinar matahari.

\section{LANDASAN TEORI}

\section{Solar Cell}

Prinsip kerja cell surya (solar cell) adalah berdasarkan konsep $P-N$ junction. Sel yang terdiri dari semiconductor jenis $P$ dan $N$ yang membentuk sambungan $P-N$, lapisan antirefleksi, dan substrat logam sebagai tempat mengalirnya arus dari lapisan tipe- $\mathrm{n}$ (elektron) dan tipe-p (hole).

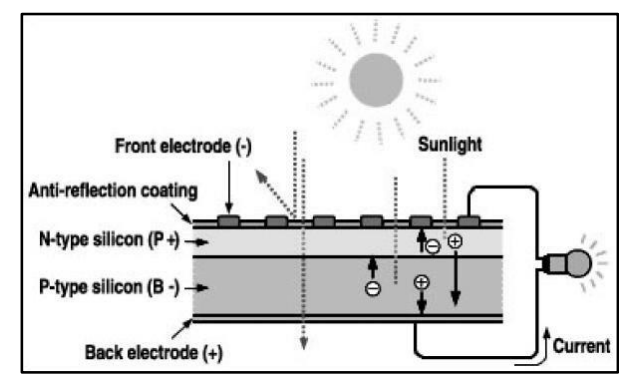

Gambar 2.1 Struktur sambungan $P-N$ pada silicon cell surya[3]

Semikonduktor tipe-N didapat dengan mengisi silikon dengan unsur dari golongan Vsehingga terdapat kelebihan elektron valensi dibanding atom sekitar. Pada sisi lain semikonduktor tipe-p didapat dengan mengisi golongan III sehingga electron valensinya defisit satu dibanding atom sekitar. Ketika dua tipe material tersebut mengalami kontak maka kelebihan elektron dari tipe $N$ berdifusi pada tipe- $P$. Sehingga area pengisi- $N$ akan bermuatan positif sedangkan area doping- $P$ akan bermuatan negatif. Medan elektrik yan terjadi antara keduanya mendorong elektron kembali ke daerah $-N$ dan hole ke daerah- $P[3]$. Pada proses ini terlah terbentuk $P-N$ junction. Dengan menambahkan kontak logam pada area $P$ dan $N$ maka telah terbentuk diode. Pada gambar 2.2 ditunjukan bentuk solar Cell.

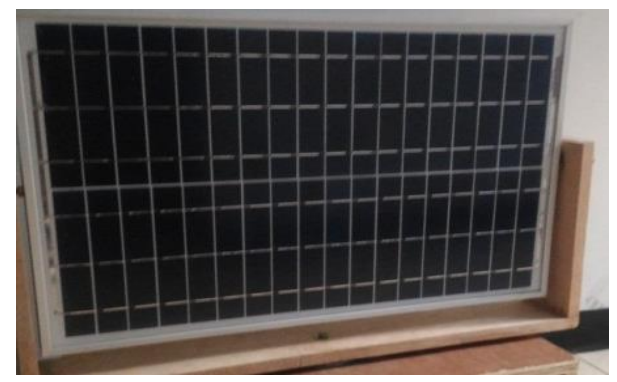

Gambar 2.2 Bentuk Solar Cell

\section{LDR (Light Dependent Resistor)}

LDR ( Light Dependent Resistor) adalah sebuah sensor dengan mengalami perubahan resistansi berdasarkan kuat cahaya yang diterima. Besar kecilnya tahanan $L D R$ didapat seberapa besar kuat cahaya diterima, semakin besar cahaya diterima maka tahanan semakin berkurang dan begitu sebaliknya semakin kecil cahaya diterima maka tahanan akan bertambah. Tahanan $L D R$ pada saat gelapa bisa mencapai 10
$M \Omega$ dan pada keadaan terang akan turun mencapai $150 \Omega$. $L D R$ terbuat dari ba-han semikonduktor seperti kadmium sulfidatr[4]. Dengan bahan ini energi dari cahaya yang jatuh menyebabkan lebih banyak mua-tan yang dilepas atau arus listrik meningkat. Artinya resistansi bahan telah mengalami penurunan.

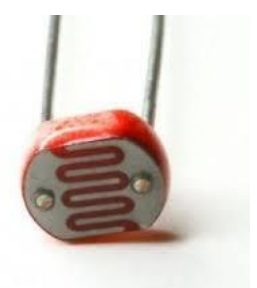

Gambar 2.3 Bentuk fisik $L D R[4]$

\section{Motor DC}

Motor DC merupakan perangkat mesin listrik dengan mengubah besaran listrik menjadi mekanis melalui medan elektromagnetis. Motor $D C$ memerlukan tegagan searah untuk memyuplai belitan stator (bagian belitan yang tidak berputar) dan rotor (bagian belitan yang berputar) agar dapat menghasilkan medan elektro magnetis sehinga dapat berputar. Diagram sederhana motor $D C$ dapat dilihat dibawah ini:

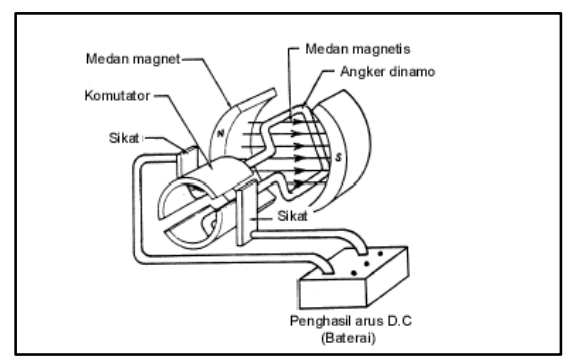

Gambar 2.4 Diagram sederhana motor DC[5]

Prinsip kerja dari motor arus searah $(D C)$ adalah dengan membalik fasa tegangan positif menggunakan sikat (komutator), dengan demikian arus yang bebalik arah melalui kumpran jangkar yang berputar di daerah medan magnet permanen. Catu daya batere yang mengalir melui sikat (komutator) dua bagian cincin tersebut terhubung ke ujung belitan rotor. Agar proses perputaran motor $D C$ sempurna, maka tegangan supplai harus lebih besar dari tegangan gerak yang dihasilkan oleh lawanya, dengan memberi arus pada kumparan jangkar yang dilindungi oleh medan magnet maka terjadila perputaran. Pada gambar 2.4 adalah gambar bentuk motor DC yang dilengkapi dengan reducer spped:

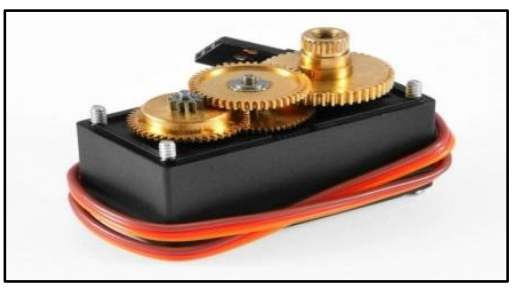

Gambar 2.5 Motor DC dilengkapi dengan reducer.[6] 
Motor dc pada penelitian ini menggunakan type motor $D C$ dengan type MG 996, motor $D C$ jenis ini memiliki tingakat kekuatan lebih besar dikarenakan menggunakan tambahan gearbox sebagai pengatur rasio torsi dan kecepatan motor.

\section{Sensor Arus}

Dalam pengisian batere dari solar cell, dibutuhkan sensor arus sebagai pemonitor arus batere dan dijdikan juga sebagai pengontrol autocarger yang dikirim ke mikrokontroller. Sensor disini digunakan sensor hall effek acs 712 dimana sensor ini sebagai pengganti resistor shunt dengan ukuran relative kecil. Prinsip kerja dari sensor arus acs 712 adalah dimana arus listrik mengalir ke beban sehingga menimbulkan medan magnet pada IC ACS 712 dibagian dynamic offset dan dikuatkan oleh amplifier dan difilter sebelum didijadikan output.

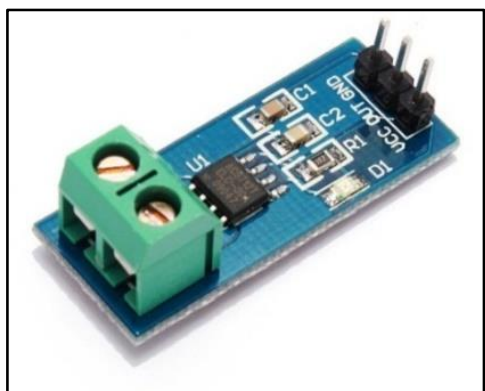

Gambar 2.6 Kit sensor arus ACS 712/30A[7]

Fungsi pin sensor Arus ACS 712:

a. Pin VCC sebagai sumber tegangan sensor.

b. Pin OUT sebagai tegangan keluaran sensor.

c. Pin GND sebagai ground

d. Terminal utama dihubung seri dengan beban.

Berikut grafik antara arus yang dilewati dengan tegangan yang dikeluarkan:

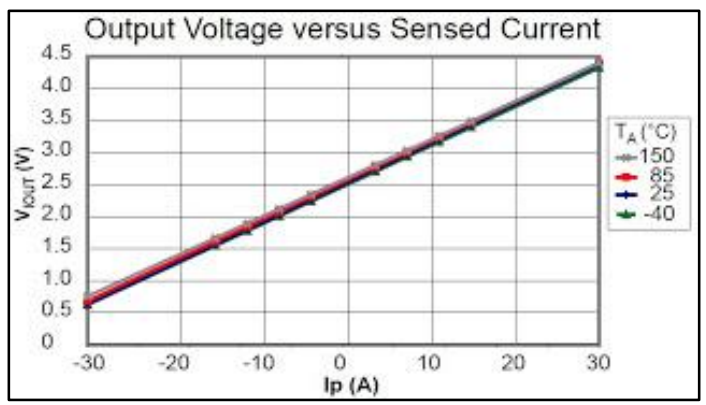

Gambar 2.7 Grafik arus terhadap tegangan output[7]

Dapat dilihat bahwah tegnagan output antara 0-5 VDC dengan perbandingan arus $-30 \mathrm{~A}-30 \mathrm{~A}$, pada kondisi tidak berbeban tegangan output sensor sebesar 2,5 VDC dengan kondisi arus $0 \mathrm{~A}[7]$

\section{Mikrokontroller Atmega16}

Mikrokontroler Atmegal6 merupakan mikrokontroler keluarga $A V R$, dimana $I C$ ini memiliki beberapa keungulan dibandingkan dengan mikrokontroler kelurga yang sebelumnya yaitu MCS-51 dan 52. Adapun kelebihan IC Atmegal6 ini adalah sudah memiliki $A D C$ internal 8 dan 10 bit, sehingga sangat cocok untuk aplikasi yang memerlukan sensor sebagai media pembacaan kondisi luar. Pemrograman mikrokontroler ini bisa kita lakukan dengan bahasa tinggi yaitu Basic, dengan menggunakan media software Bascom $A V R$. Berikut konfigurasi PIN atmegal6:

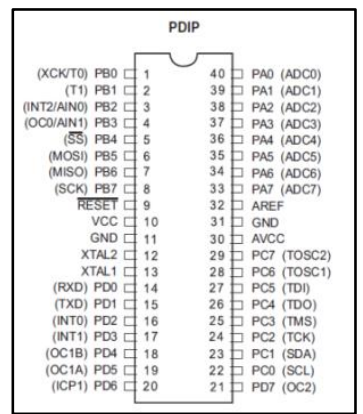

Gambar 2.8 Konfigurasi PIN atmegal6[8].

Berikut ini adalah fungsi-fungsi dari pin out Atmegal6 :

1. $\quad V C C$, merupakan pin yang berfungsi sebagai pin masukkan catu daya.

2. GND (Ground), merupakan pin ground.

3. PORTA (PORTA0-7), merupakan pin I/O dua arah dan berfungsi khusus sebagai pin masukan ADC.

4. PORTB (PORTB0-7), merupakan pin I/O dua arah dan fungsi khusus sebagai pin Timer/counter, komparator analog dan SPI.

5. PORTC (PORTC0-7), merupakan pin I/O dua arah dan fungsi khusus yaitu TWI, Komparator Analog, dan Timer Oscilator.

6. PORTD (PORTD0-7), merupakan pin I/O dua arah dan fungsi khusus yaitu Komparator Analog, Interupsi eksternal dan komunikasi serial USART.

7. RESET, merupakan dalah pin untuk mereset mikrokontroler.

8. XTAL1 dan XTAL2 merupakan pin untuk exsternal clock.

9. AVCC merupakan pin masukan untuk tegangan ADC.

10. AREF merupakan pin masukan untuk tegangan referens ADC.

Atmega16 memiliki flash memory sebesar 16 Kbytes untuk memori program.. Dan memiliki 608 alamat memori data yang terbagi menjadi 3 bagian, yaitu 32 buah register umum, 32 buah register I/O, dan 512 bytes EEPROM[8]. 
6. $L C D$

Liquid Crystal Display (LCD) merupakan sebuah teknologi layar digital yang menghasilkan citra pada sebuah permukaan yang rata dengan memberi sinar pada kristal cair dan filter berwarna, yang mempunyai struktur molekul polar, diapit antara dua elektroda yang transparan. Bila medan listrik diberikan, molekul menyesuaikan posisinya pada medan, membentuk susunan kristalin yang mempolarisasi cahaya yang melaluinya[9]. Berikut tabel port $L C D$ :

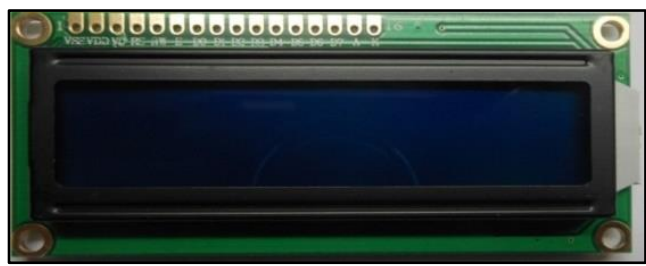

Gambar 2.9 Bentuk Fisik LCD 2 x 16[10]

\section{IC driver motor $L 293 D$}

IC driver L293D adalah sebuah didesain kusus sebagai driver motor DC dan dapat dikendalikan dengan rangkaian analog maupun mikrokontroller. Motor $D C$ yang dikontrol dengan IC L293D tidak perlu dihubungkan ke ground maupun sumber positif, karena motor langsung disambung ke output IC. Karena didalam IC $l 293 D$ system drver yang digunakan adalah totoem pole, jadi terdapat 4 buah driver motor $D C$ berdiri sendiri dengan kemampuan mengalirkan arus sebesar $1 A$ tiap drivernya[11]. Konstruksi dalam driver motor DC adalah sebagai berikut:

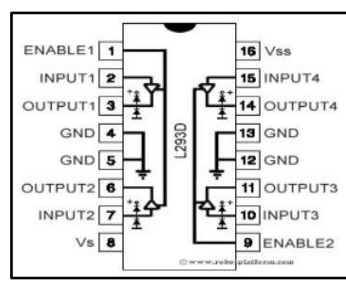

Gambar 2.10 Konstruksi dalam dan fungsi pin IC $1293 D[11]$

Fungsi PIN driver motor DC IC L293D:

1. PIN VCC (VCC1,VCC2) adalah jalur input tegangan sumber DC,dimana VCCl digunakan sebagai control driver dan VCC2 digunakan sebagai VCC motor.

2. PIN ground adalah jalur yang harus terhubung ke ground.

3. PIN EN (enable,EN1.2, EN 3.4) berfungsi sebgai perintah driver untuk menggerakan motor DC.

4. $\quad P I N$ In (Input $1 \mathrm{~A}, 2 \mathrm{~A}, 3 \mathrm{~A}, 4 \mathrm{~A}$ ) sinyal kendali putara motor $D C$.

PIN Out (Output 1Y,2Y,3Y,4Y) adalah jalur output masing- masing ke motor $D C[11]$.

\begin{tabular}{|l|l|l|}
\hline No. & Alamat PORT & Variabel / Penggunaan \\
\hline 1. & PORT.AO & Sensor LDR I \\
\hline 2. & PORT.AI & Sensor LDR 2 \\
\hline 3. & PORT.A2 & Sensor LDR 3 \\
\hline 4. & PORT.A3 & Sensor LDR 4 \\
\hline
\end{tabular}

\section{METODOLOGI PENELITIAN}

\section{DIAGRAM SISTEM}

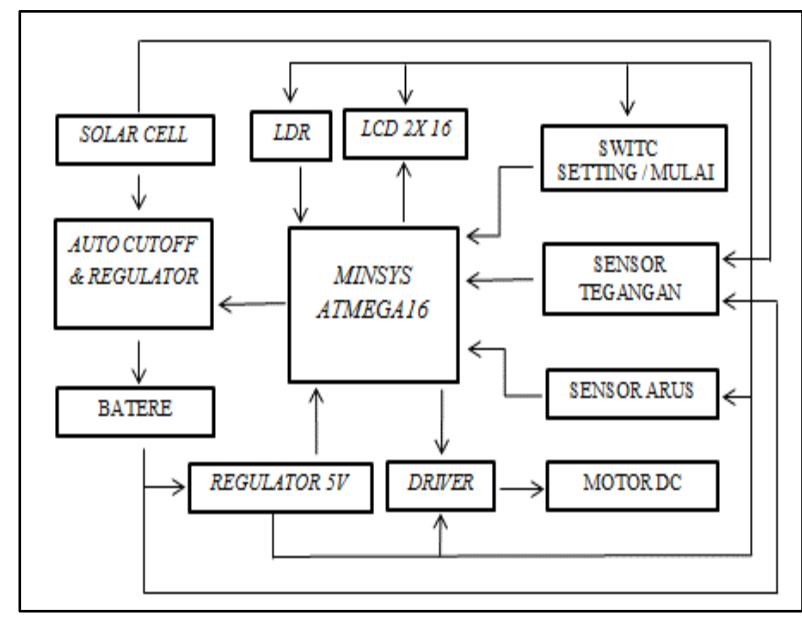

Gambar 3.1 Diagram sistem

Block diagram diatas dapat dijelaskan sebagai berikut:

1. $L D R$ mengirim data dimana posisi sinar matahari yang paling terang.

2. Mikrokontroller mengolah menjadi data digital dan memerintah motor berputar.

3. Tegangan solar cell dimasukan ke regulator untuk diturunkan menjadi 14 Volt.

4. Sensor arus dan sensor tegangan batere, sensor tegangan solar cell mengirim ke mikrokontroler unruk di tampilkan hasl pengukuran.

5. Switch di gunakan sebagi setting set poin data dan setting menu metering, serta setting manual.

\section{PERANCANGAN HARDWARE}

a. Pemasangan Sensor dan motor

Pada tahap pertama perencanaan hardware control tracker solar cell dimana $L D R$ sebagai sensor penerima cahaya sinar matahari, perubahan tegangan dari rangkaian $L D R$ akan diterimah oleh mikrokontroller dan masuk di posisi PORT $A D C(P A O-P A 3)$ untuk dilakukan pengolahan data.

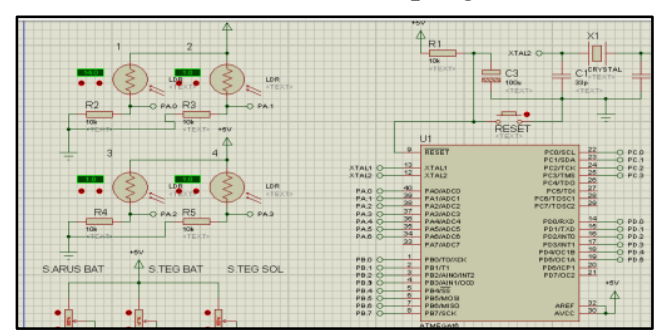

Gambar 3.2 Wiring koneksi LDR ke mikrokontroller. 


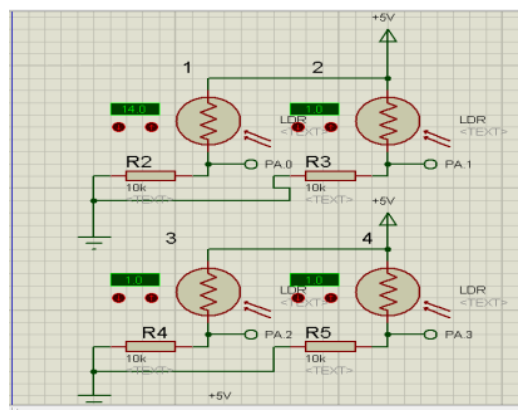

Gambar 3.3 Rangkaian pembagi tegangan $L D R$.

Tabel 3.1 Rangkaian pembagi tegangan $L D R$

\begin{tabular}{|l|l|l|}
\hline No. & Alamat PORT & Variable / Penggunaan \\
\hline 1. & PORTD.0 & Motor 1 putar clockwise \\
\hline 2. & PORTD.1 & Motor 1 putar counterclockwise \\
\hline 3. & PORTD.2 & Motor 2 putar clockwise \\
\hline 4. & PORTD.3 & Motor 2 putar counterclockwise \\
\hline 5. & PORTD.4 & Kecepatan motor 1 \\
\hline 6. & PORTD.5 & Kecepatan motor 2 \\
\hline
\end{tabular}

Motor akan berputar sesuai perintah sensor, motor akan tersambung di PORTD 0 - 5 sebagai output dengan masingmasing motor menggunakan 2 output yang digunakan sebagai pengatur parah putaran motor 1 dan motor 2. Berikut Tabel Penggunaan PORT.D0 - PORTD.5 Pada IC Atmegal6:

Tabel 3.1 Penggunaan kaki $I C$ driver motor

\section{b. Pemasangan sensor arus dan LCD}

pemasangan $L C D$ dan penyambungan yang di gunakan sebagai penampil data tegangan dan arus batere. Pada penyambungan kaki $L C D$ adalah alamat kaki yang akan dipakai tidak semua dari 16 PIN. Dan perlu di perhatikan adalah polaritas tegangan $V C C$ dan Ground, port data, $R S, E$, $R / W$ tidak boleh terbalik tegangan kerja maximal $L C D$ adalah sebesar $5 \mathrm{~V}$. Berikut gambar penyambungan $L C D$ :

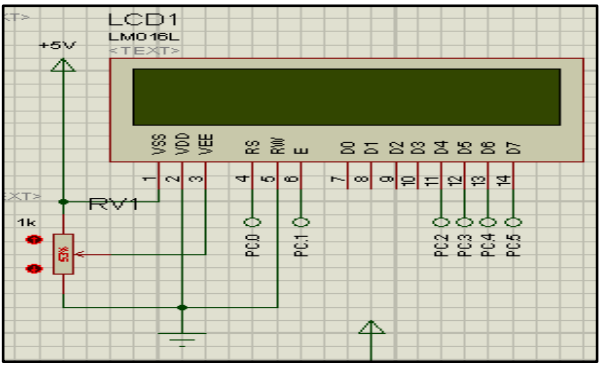

Gambar 3.4 Penyambungan LCD ke mikrokontroller.[10]

Penyambungan sensor arus menggunakan modul sensor ACS 712 dihubung seri antara regulator tegangan dari solar cell dengan batere dan digunakan sebagai sensor autocharger pada saat kondisi batere penuh. Desain penyambungan sensor ACS 712 dapat dilihat pada gambar dibawah ini:

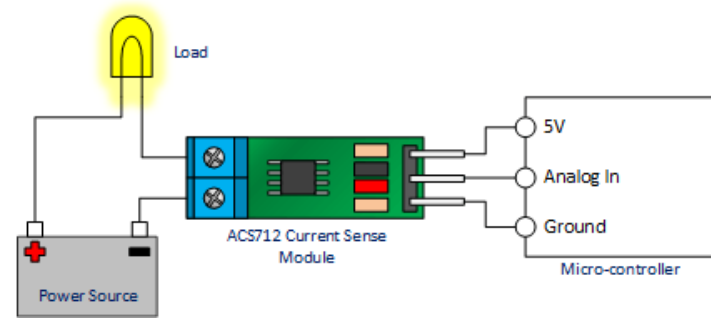

Gambar 3.5 Penyambungan sensor arus $A C 712[7]$.

Dari gambar 3.5 dapat dilihat penyambungan antara beban lampu dengan sensor sehingga dapat dikirim signal analog ke mikrokontroller agar dapat di tampilkan arus pengisian

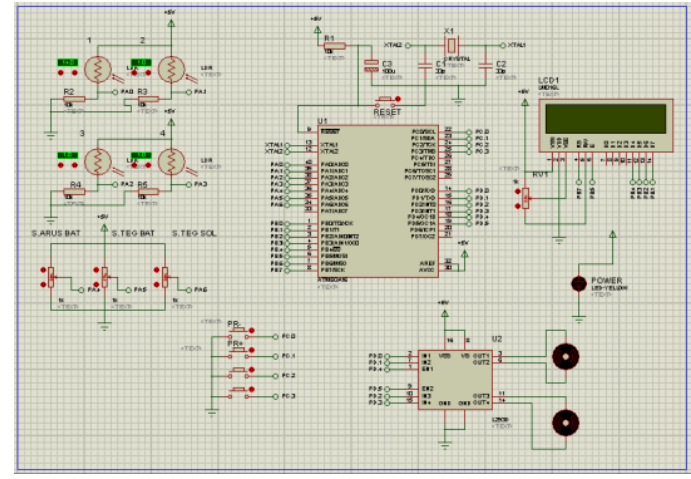

Gambar 3.6 Rangkaian keseluruan system kontrol 


\section{PENGUJIAN DAN HASIL}

\section{Pengujian}

Sistem ini di gunakan sebagai mengontrol sebuah solar cell agar tepat berhadapan dengan sinar matahari agar mendapat energi yang maximal sehingga kemampuan daya yang di hasilkan solar cell lebih baik dan di bandingkan dengan solar cell yang tidak menggunakan sistem kontrol. Dengan menggunakan mikrokontroller ATMEGAl6 agar dapat di monitoring berupa tampilan dan pemberian perintah, dari perangkat itu dapat dilihat kondisi masing masing alat yang dikontrol sehingga mempermudah dalam pengambilan data dan pengoperasian. Setelah perancangan sistem selesai dilakukan, maka proses selanjutnya yaitu melakukan pengujian kinerja dari alat tracker solar cell. Berikut langkah langkah pengujian:

1. Menghubungkan semua minimum sistem ke regulator catu daya, serta sensor sensor, switch, $L C D$ ke mikrokontroller.

2. Menghubungkan masing masing motor ke driver, menghubungkan batere ke regulator, menghubungkan solar cell ke regulator.

3. Menghubungkan downloader ke computer dengan kabel USB dan menghubungkan minimu sistem ke downloader.

4. Jalankan program BASCOM AVR dan KHAZAMA upload program yang sudah dibuat ke minimum sistem.

5. Aktifkan sakelar power untuk menjalankan minimum sistem, regulator, motor.

Prinsip kerja alat ini adalah solar cell menghadap arah sinar matahari dengan dengan sebuah mekanik yang digerakan dengan menggunaka 2 motor DC, pergerakan motor diatur berdasarkan dari perintah sensor yang membaca sinar matahari dengan logika membandingkan data antar sensor.

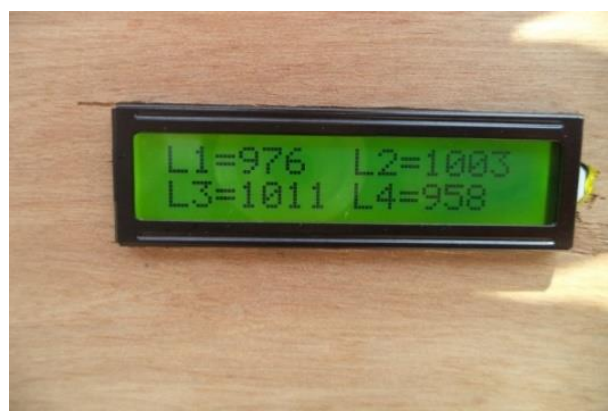

Gambar 4.1 Tampilan data sensor tidak sama rata

Dari data dia atas dapat dilihat hasil pembacaan data dari sensor LDR ke layar LCD yang tidak sama rata yang di gunakan sebagai perintah motor berputar.

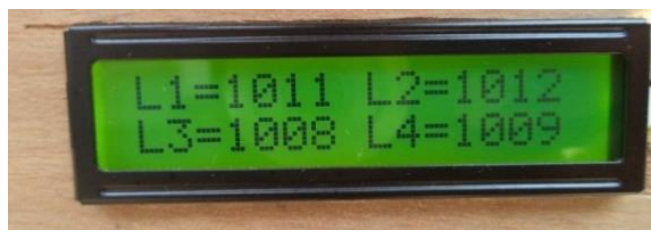

Gambar 4.2 Tampilan data sensor tidak sama rata
Dari data dia atas dapat dilihat hasil pembacaan data dari sensor LDR ke layar LCD yang sama rata yang di gunakan sebagai perintah motor untuk berhenti di posisi arah datangnya sinar mtahari.

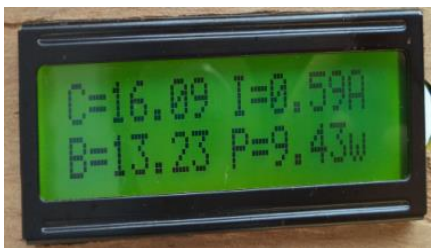

Gambar 4.3 Tampilan metering

Tampilan $C$ adalah tegangan solar cell, tampilan I adalah arus saat pengisian batere, dan tampilan $\mathrm{B}$ adalah kondisi tegangan Batere, $\mathrm{P}$ adalah kondisi daya yang mengalir. Arus pengisian menunjukan 0,59 A, jika Arus pengisian menjukan angka di bawah " 0 " atau minus berarti tidak ada proses pengisian

\section{Hasil}

Tabel 4.1 Pengujian hari ke 1

\begin{tabular}{|c|c|c|c|c|c|c|c|c|c|c|c|}
\hline \multirow{2}{*}{ NO. } & \multicolumn{6}{|c|}{ SOLARCELL PASIF } & \multicolumn{4}{|c|}{ SOLARCELL TRACKER } & \multirow{2}{*}{ KETERANGAN } \\
\hline & HAKTU & $\overline{\mathrm{ARUS} \text { (A }}$ & TEGANGAN(V) & DAYA & 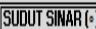 & BATERE(V) & $\mid$ ARUS(A) & TEGANGAN (V) & & BATERE (V) & \\
\hline 1 & 7.40 & 0.22 & 14.32 & 3.14 & -39 & 11.30 & 0.44 & 14.66 & 6.43 & 11.38 & \multirow{32}{*}{$\begin{array}{c}\text { Beban Lampu } \\
\text { LED 12V/3 } \\
\text { Hatt \& kontrol } \\
\text { Tracker, } \\
\text { Motor } \\
\text { (Penguian } \\
\text { Tanggal 10-8 } \\
\text { 2017) }\end{array}$} \\
\hline 2 & 7.50 & 0.29 & 14.66 & 4.3 & -37.5 & 11.7 & 0.51 & 14.83 & 6.51 & 11.86 & \\
\hline 3 & 8.00 & 0.37 & 14.84 & 4.34 & .30 & 11.95 & 0.66 & 15.1 & 9.91 & 12.13 & \\
\hline 4 & 8.10 & 0.44 & 14.94 & 6.54 & -28.5 & 12 & 0.66 & 15.14 & 9.98 & 12.2 & \\
\hline 5 & 8.20 & 0.44 & 14.96 & 6.55 & -27 & 12 & 0.66 & 15.16 & 9.94 & 12.13 & \\
\hline 6 & 8.30 & 0.44 & 15.00 & 6.60 & -25.5 & 12 & 0.73 & 15.21 & 11.16 & 12.26 & \\
\hline 7 & 8.40 & 0.44 & 15.14 & 6.65 & -24 & 12.21 & 0.66 & 15.29 & 10.29 & 1234 & \\
\hline 8 & 8.50 & 0.51 & 15.2 & 7.76 & -22.5 & 12.28 & 0.73 & 15.36 & 1125 & 12.41 & \\
\hline 9 & 9.00 & 0.59 & 15.36 & 9.00 & -15 & 12.42 & 0.73 & 15.42 & 1125 & 12.47 & \\
\hline 10 & 9.10 & 0.59 & 15.40 & 9.02 & -13.5 & 12.47 & 0.73 & 15.47 & 11.28 & 125 & \\
\hline$\pi$ & 9.20 & 0.66 & 15.49 & 10.20 & -12 & 12.52 & 0.81 & 15.53 & 1255 & 1257 & \\
\hline 12 & 9.30 & 0.73 & 15.57 & 1140 & -10.5 & 12.56 & 0.81 & 15.6 & 1256 & 12.63 & \\
\hline 13 & 9.40 & 0.73 & 15.62 & 11.46 & -9 & 12.62 & 0.81 & 15.68 & 12.62 & 12.68 & \\
\hline 14 & 9.50 & 0.66 & 15.62 & 10.25 & -7.5 & 1263 & 0.73 & 15.68 & 1148 & 1273 & \\
\hline 15 & 10.00 & 0.73 & 15.72 & 11.51 & 0 & 12.76 & 0.81 & 15,72 & 12.62 & 12.78 & \\
\hline 16 & 10.10 & 0.73 & 15.75 & 1154 & 15 & 12.83 & 0.81 & 15.75 & 12.65 & 12.83 & \\
\hline 17 & 10.20 & 0.66 & 15.75 & 10.38 & 3 & 1284 & 0.73 & 15.79 & 11.56 & 12.86 & \\
\hline 18 & 10.30 & 0.66 & 15.75 & 10.39 & 4.5 & 12.86 & 0.73 & 15.79 & 1157 & 12.89 & \\
\hline 19 & 10.40 & 0.59 & 15.83 & 9.27 & 6 & 12.89 & 0.66 & 15.86 & 10.46 & 12.92 & \\
\hline 20 & 10.50 & 0.59 & 15.88 & 9.31 & 7.5 & 12.96 & 0.66 & 15.9 & 10.48 & 12.97 & \\
\hline 21 & 1100 & 0.59 & 15.92 & 9.33 & 15 & 13.00 & 0.66 & 15.96 & 10.48 & 13.02 & \\
\hline 22 & 1110 & 0.66 & 15.98 & 10.49 & 16.5 & 13.05 & 0.66 & 15.98 & 10.56 & 13.05 & \\
\hline 23 & 1120 & 0.66 & 16.01 & 10.56 & 18 & 13.07 & 0.66 & 15.99 & 10.56 & 13.08 & \\
\hline 24 & $\pi 130$ & 0.51 & 15.96 & 8.18 & 19.5 & 13.07 & 0.51 & 15.99 & 8.2 & 13.08 & \\
\hline 25 & 1140 & 0.66 & 16.12 & 10.58 & 21 & 13.13 & 0.73 & 16.12 & 11.81 & 13.18 & \\
\hline 26 & 1150 & 0.59 & 16.11 & 9.39 & 22.5 & 13.2 & 0.66 & 16.14 & 10.46 & 13.21 & \\
\hline 27 & 1200 & 0.59 & 16.13 & 9.47 & 30 & 13.25 & 0.66 & 16.18 & 10.62 & 13.26 & \\
\hline 28 & 210 & 0.51 & 16.20 & 8.3 & 31.5 & 13.28 & 0.59 & 16.22 & 9.46 & 13.29 & \\
\hline 29 & 1220 & 0.44 & 16.14 & 7.09 & 33 & 13.2 & 0.59 & 16.25 & 9.55 & 13.33 & \\
\hline 30 & 1230 & 0.44 & 16.14 & 7.09 & 34.5 & 13.35 & 0.59 & 16.25 & 9.55 & 13.33 & \\
\hline 31 & 1240 & 0.59 & 16.33 & 9.52 & 36 & 13.37 & 0.66 & 16.33 & 10.76 & 13.39 & \\
\hline 32 & 1250 & 0.37 & 16.24 & 5.95 & 37.5 & 13.31 & 0.59 & 16.29 & 9.55 & 13.36 & \\
\hline \multicolumn{2}{|c|}{ Rata Rata } & 0.55 & 14.71 & 8.10 & 1.125 & 12.70 & 0.68 & 15,71 & 10.57 & 12.75 & \\
\hline
\end{tabular}

Dari data tabel diatas dilakukan pengujian pada hari pertama kenaikan daya sebesar 30,37\%, tegangan $6,79 \%$ dan arus sebesar 22,34\%. Dengan menggunakan beban lampu $12 \mathrm{~V}$ 12 dan kontrol tracker.

Tabel 4.2 Pengujian hari ke 2

\begin{tabular}{|c|c|c|c|c|c|}
\hline \multicolumn{3}{|c|}{ SELISIH } & \multicolumn{3}{c|}{ PROSENTASE KENAIKAN (\%) } \\
\hline Arus Isi (A) & Tegangan Isi (V) Daya Isi (W. & Arus Isi & Tegangan Isi & Daya Isi \\
\hline 0.12 & 1.00 & 2.46 & 22.34 & 6.79 & 30.37 \\
\hline
\end{tabular}


Dari data tabel diatas dilakukan pengujian pada hari pertama kenaikan daya sebesar $40,77 \%$, tegangan $7,42 \%$ dan arus sebesar $31,51 \%$. Dengan menggunakan beban lampu $12 \mathrm{~V}$ 12 dan kontrol tracker.

Tabel 4.3 Pengujian hari ke 3

\begin{tabular}{|c|c|c|c|c|c|c|c|c|c|c|c|}
\hline \multirow{2}{*}{ NO. } & \multicolumn{6}{|c|}{ 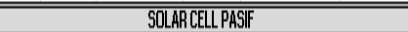 } & \multicolumn{4}{|c|}{ 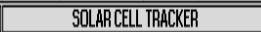 } & \multirow{2}{*}{ KETERAMGGAN } \\
\hline & WAKTU & $\widehat{\mathbb{A R} U S(\mathbb{A})}$ & TEGANGAN (U) & DAYA(P) & 1) SUDUT SNARI & BATERE[V] & ARISIA & TEGAMGAMN(I) & DAYA & $\overline{\text { BATERE (V) }}$ & \\
\hline 1 & 7.40 & 0.25 & 14.35 & 359 & -39 & 11.2 & 0.44 & 14.66 & 6.45 & 11.6 & \\
\hline 2 & 7.50 & 0.29 & 14.66 & 4.25 & -375 & $11: 58$ & 0.51 & 11.83 & 756 & 117 & \\
\hline 3 & 800 & 0.37 & 14.84 & 5.49 & .30 & 11.62 & 0.66 & 15.1 & 997 & 11.81 & \\
\hline 4 & 810 & 0.44 & 14.94 & 6.57 & -285 & 11,66 & 0.66 & 15.14 & 9.99 & 11.87 & \\
\hline 5 & 8.20 & 0.44 & 14.96 & 6.58 & -27 & 11.7 & 0.73 & 15.16 & 11.07 & 19.96 & \\
\hline 8 & 830 & 0.59 & 15000 & 7.65 & -25.5 & $\overline{111.76}$ & 0.73 & 15.21 & 10110 & 20.4 & \\
\hline 7 & 8.40 & 0.5 & 15.00 & 7.54 & -24 & $\overline{11180}$ & 0.75 & 15.35 & 115.51 & 2,15 & \\
\hline 8 & 8.50 & 0.55 & 15.16 & 8.34 & .225 & 11.34 & 0.76 & 15.36 & 11.67 & 2.21 & \\
\hline 9 & 900 & 0.55 & 15.36 & 8.45 & -75 & 11180 & 0.76 & 15.42 & 1172 & 2.24 & \\
\hline 10 & 9.10 & 0.55 & 15.40 & 8.47 & -13.5 & 11.92 & 0.79 & 1555 & 1228 & 123 & \\
\hline 11 & 9.20 & 0.6 & 15.52 & 931 & -12 & 12 & 0.81 & 15.61 & 12.64 & 238 & \\
\hline 12 & 930 & 0.73 & 1562 & 1140 & -110.5 & 1288 & 0.81 & 1565 & 1268 & 242 & \\
\hline 13 & 9.40 & 0.73 & 15.62 & 1140 & -9 & 1214 & 0.81 & 57 & 1272 & 2.47 & Beban Lampu \\
\hline 14 & 9.50 & 0.72 & 1562 & 11.25 & -7.5 & 1220 & 0.81 & 15.73 & 12.74 & 2.52 & LED 12V/3 \\
\hline 15 & 10,000 & 0.73 & 15.72 & 11.48 & 0 & 1225 & 0.81 & 58 & 1280 & 255 & Hat \& lontrol \\
\hline 16 & 10,10 & 0.73 & 1575 & 11.50 & 15 & 1229 & 0.81 & 15.86 & 12.85 & 262 & Tracker, \\
\hline 17 & 1020 & 0.66 & 15.7 & 10.36 & 3 & 1233 & 0.73 & 15.82 & 11155 & 266 & Molor \\
\hline 18 & 10.30 & 0.66 & 15.73 & 10.36 & 4.5 & 1242 & 0.73 & 15.79 & 11153 & 271 & (Pengyijan \\
\hline 19 & 10.40 & 0.62 & 1573 & 9.75 & 6 & 12.47 & 0.78 & 15.86 & 1237 & 128 & Tanggal 13- \\
\hline 20 & 10.50 & 0.64 & 1578 & 10.10 & 75 & 1255 & 0.78 & 59 & 1240 & 285 & 08-207] \\
\hline 27 & 11000 & 0.63 & 15.82 & 9.97 & 5 & 1280 & 0.8 & 15.96 & 1277 & 292 & \\
\hline 22 & 211,10 & 063 & 15.92 & 10.03 & 165 & 1285 & 0.79 & 15.98 & 1262 & 298 & \\
\hline 23 & 41120 & 0.66 & 15.97 & 10.54 & 13 & 12.72 & 0.78 & 15.95 & 1260 & 13 & \\
\hline 24 & 1130 & 0.62 & 1586 & 9.83 & 195 & 1278 & 0.73 & 15.89 & 11600 & 1302 & \\
\hline 25 & (11.40 & 0.66 & 15.9 & 10.49 & 21 & 1284 & 0.73 & 15.89 & 116.60 & 13.04 & \\
\hline 26 & 11150 & 0.59 & 15.68 & 9.25 & 225 & 1289 & 0.66 & 15.75 & 10.40 & 13.03 & \\
\hline 27 & 1200 & 0.59 & 1566 & 9.25 & (1) & 1225 & 0.66 & 15,71 & 10.37 & 1307 & \\
\hline 28 & 12,10 & 0.51 & 1555 & 9.93 & 315 & 1238 & 0.59 & $15.66^{\circ}$ & 9.25 & 13.1 & \\
\hline 29 & 1220 & 0.44 & 15.48 & 6.81 & 3 & 13.13 & 0.59 & 15.67 & 9.25 & 313 & \\
\hline 30 & 1230 & 0.44 & 15.47 & 6.81 & 34.5 & 13.8 .8 & 0.59 & 15.64 & 9.23 & 3.15 & \\
\hline 31 & 12.40 & 0.39 & 15.32 & 5.97 & 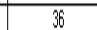 & 13.12 & 0.45 & 15.44 & 6.95 & 318 & \\
\hline 32 & 1250 & 0.37 & 1535 & 5.68 & 37.5 & 13,15 & 0.45 & 5.4 & 6.93 & 13.2 & \\
\hline & Rata & 0.56 & 14.55 & 8.13 & 1.13 & 12,70 & 0.70 & 13,58 & 10,99 & 12,58 & \\
\hline
\end{tabular}

\begin{tabular}{|c|c|c|c|c|c|}
\hline \multicolumn{3}{|c|}{ SELISIH } & \multicolumn{2}{c|}{ PROSENTASE KENAIKAN (\%) } \\
\hline Arus Isi (A Tegangan Is & Daya lsi ( & Arus Isi & Tegangan Is & Daya Isi \\
\hline 0.15 & 1.03 & 2.84 & 26.35 & 7.09 & 34.98 \\
\hline
\end{tabular}

Dari data tabel diatas dilakukan pengujian pada hari pertama kenaikan daya sebesar $34,98 \%$, tegangan $7,09 \%$ dan arus sebesar 26,35\%. Dengan menggunakan beban lampu $12 \mathrm{~V} 12$ dan kontrol tracker.

Pada ketiga hasil pengujian ditunjukan hasil perbandingan solar cell dengan sistem pasif dengan kemiringan 45 derajat menghadap ke utara dan solar cell menggunakan tracker, didapat hasil pengujian yang dilakukan pada tanggal 10, 12, 13 Agustus 2017 mulai dari pagi sampai siang hari dengan data setiap menit dalam penggambilan jumlah data sebesar 32 kali. Didapat perbandingan selesih perbandingan dengan prosentase sebesar $35,37 \%$ pada sisi daya, $7,10 \%$ pada sisi tegangan, dan $26,73 \%$ pada sisi arus Pengisian.

\begin{tabular}{|c|c|c|c|c|c|}
\hline \multicolumn{3}{|c|}{ SELISIH } & \multicolumn{2}{c|}{ PROSENTASE KENAIKAN (\%) } \\
\hline Arus Isi (A) Tegangan Is & Daya Isi (W) & Arus Isi & Tegangan Is & Daya Isi \\
\hline 0.15 & 1.09 & 2.93 & 31.51 & 7.42 & 40.77 \\
\hline
\end{tabular}

Tabel 4.4 Prosentase hasil rata rata pengujian selama 3 hari

\begin{tabular}{|c|c|c|c|c|c|}
\hline \multicolumn{3}{|c|}{ JUNLAH 3 KALIPENGUJAN } & \multicolumn{3}{c|}{ RATA RATA 3 KALIPENGUJIAN (\%) } \\
\hline Arus Isi & Tegangan Isi & Daya lsi & Arus Isi & Tegangan Isi & Daya Isi \\
\hline 80.20 & 21.31 & 106.12 & 26.73 & 7.10 & 35.37 \\
\hline
\end{tabular}

Dengan kemiringan solar cell pasif sebesar $45^{\circ}$ menghadap ke utara lurus, sedangkan solar cell aktif mengikuti sinar matahari. Dengan kondisi medapatkan sudut sinar matahari yang sama, dengan persamaan:

\section{$\omega=(\mathrm{Ts}-10) \times 360 / 24$}

dapat ditentukan besar sudut sinar matahari untuk posisi pasif maupun aktif. Pada tabel 4.11 dapat dilihat besar sudut setiap 10 menit beserta kondisi grafik dengan acuan pukul 10.00 dibuat titik 0 derajat.

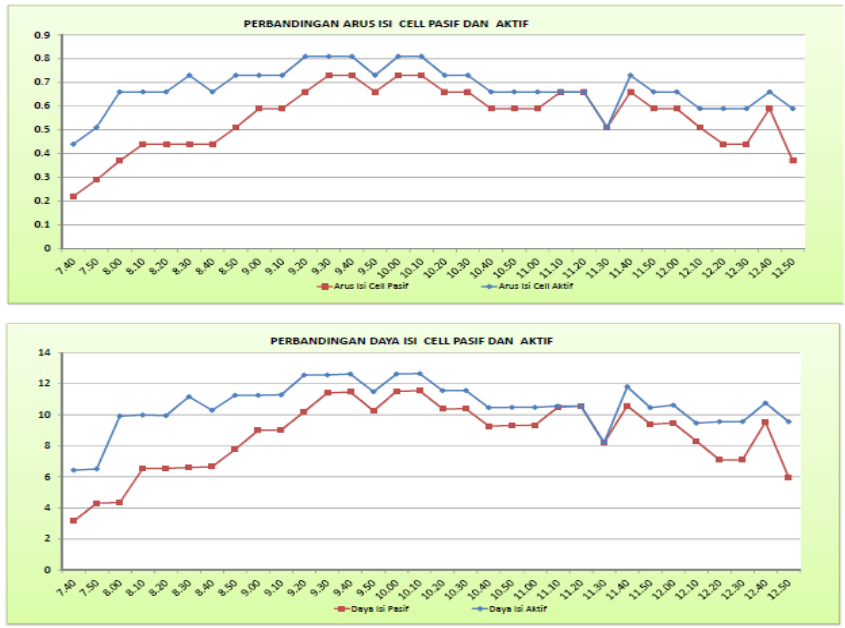

Gambar 4.4 Grafik arus solar cell pasif dengan solar cell aktif

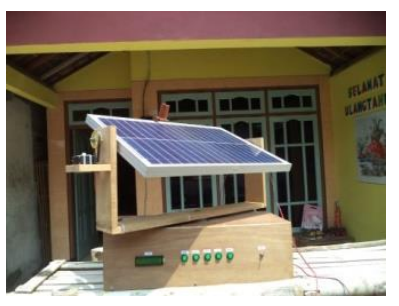

Gambar 4.5 Posisi Solar Tracker pada jam 12.00

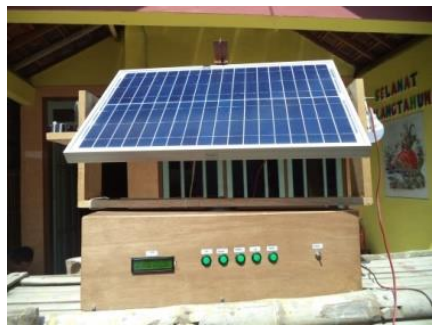

Gambar 4.5 Posisi Solar Tracker pada jam 9.30 


\section{KESIMPULAN}

Berdasarkan hasil perancangan dan pengujian yang telah dilakukan dapat diberi kesimpulan sebagai berikut:

1. Pemasangan pembatas sensor dapat mepercepat respon pergerakan sinar matahari.

2. Penggunaan tracker efisiensi daya yang di hasilkan lebih baik untuk di pagi hari, dikarenakan pada siang hari relatif mendekati sama.

3. Dengan penggunaan daya yang sesuai antara pengisian dan pengeluaran, batere masih bisa terisi dengan penuh.

4. Di dapat pemasangan solar cell dengan menggunakan tracker didapat daya isi lebih tinggi sebesar $35,37 \%$ di banding dengan solar cell pasif.Sudut penerimaan solar cell lurus $90^{\circ}$ dengan datangnya sinar matahari.

\section{REFERENSI}

[1] Jamaaluddin Jamaaluddin;Imam Robandi, "Short Term Load Forecasting of Eid Al Fitr Holiday By Using Interval Type - 2 Fuzzy Inference System ( Case Study: Electrical System of Java Bali in Indonesia )," in 2016 IEEE Region 10, TENSYMP, 2016, vol. 0, no. x, pp. 237-242.

[2] U. M. Sidoarjo, "Petunjuk praktis perancangan pentanahan sistem tenaga listrik," pp. 1-22, 2017.

[3] F. Afifudin and F. S. Hananto, "SOLAR CELL MENGGUNAKAN LENSA PEMFOKUS.”

[4] E. B. Raharjo and I. Setiawan, "MENGGUNAKAN MIKROKONTROLER ATMEGA8535,” pp. 1-10.

[5] E-educativa es, "Motor Dc," 2012.

[6] H. Torque, "MG996R," no. 6 V, pp. 7-8.

[7] “ACS712 Module Measures Currents up to 30A for as Low as \$1 Shipped.".

[8] K. I. Sram, "with 16K Bytes Programmable ATmega16 ( L )."

[9] D. Electronic, "M1632 module lcd $16 \times 2$ baris (m1632)," no. 01000001.

[10] F. S. Agung and M. Farhan, "Sistem Deteksi Asap Rokok Pada Ruangan Bebas Asap Rokok Dengan Keluaran Suara," pp. 1-9, 2009.

[11] D. Information, "L293x Quadruple Half-H Drivers," 2016. 